\title{
Non enzymatic isolation of adipose tissue and stromal vascular fraction derived cells
}

\author{
Ece ÇERÇi ${ }^{a}$, Hatice ERDOST ${ }^{\mathrm{b}, \bowtie}$ \\ Bursa Uludağ University, Faculty of Veterinary Medicine, Department of Histology and Embryology, Bursa, Turkey. \\ aRCID: 0000-0002-2740-4262; ' ORCID: 0000-0003-1547-7293

${ }^{凶}$ Corresponding author: edost $@$ uludag.edu.tr
Received date: 16.12.2019- Accepted date: 12.02 .2020

\begin{abstract}
The therapeutic potential of the adipose tissue is also supported by a source of mesenchymal stem cells (MSCs), endothelial progenitor cells, mast cells, T- lymphocyte, B lymphocyte, and adipose-resident macrophages with repairing and regenerative ability. The purpose of this study was to compare adipose tissue derived mesenchymal stem cells (ADSCs) and stromal vascular fraction cells (SVF cells) in terms of the usage of non-enzymatic isolation, detection of cell adhesion, fibroblastoid cell formation, properties of cell population, cell culture duration until 3rd passages under in-vitro culture condition. We used 3 months old, 4 male Sprague Dawley rats (mean of live weight about $250 \mathrm{~g}$ ) to examined the variation of the cell population, cell properties, phases of cellular formation, cell culturing time, subculturing duration, differences in confluency between SVF cells and ADSCs. In in-vitro expansion, ADSCs displayed higher rate of adhesiveness, homogenous cell population, faster proliferation and formation of fibroblast like cells compared to SVF cells. As a result, we showed that ADSCs have better adhesive ability, higher proliferative capacity in all of the 3 passages and require shorter time to reach confluency compared with SVF cells in vitro. These findings may contribute to future studies that deal with isolation and selection of stem cells from various tissues, as well as design clinical trials based on ADSCs and SVF cells.
\end{abstract}

Keywords: Adipose tissue derived cells, mesenchymal stem cells, stromal vascular fraction cells

\section{Adipoz doku ve stromal vasküler fraksiyon kökenli hücrelerin non enzimatik izolasyonu}

Özet: Adipoz dokusunun terapötik potansiyeli; mezenkimal kök hücreler (MKH) ile desteklenmesinin yanında endotel progenitor hücreleri, mast hücreleri, T lenfositleri ve adipoz dokusundaki makrofajların etkisi ile tedavi ve rejenerasyon potansiyeli ile de desteklenmektedir. Bu çalışmanın amacı; adipoz doku kökenli mezenkimal kök hücreler (ADMKH) ve stromal vasküler fraksiyon kökenli hücrelerin (SVF hücreleri) non enzimatik hücre izolasyonu yöntemi, hücrelerin plastik yüzeye tutunması, fibroblastoid yapının oluşumu, hücre populasyonunun özellikleri, 3. pasaja kadar in vitro kültür yönünden karşılaştırılmasıdır. Bu çalışmada, SVF hücreleri ve ADMKH'lerin arasındaki; hücre popülasyonu, hücrelerin yapısal özellikleri, hücresel gelişim fazları, hücre kültür süresi, subkültür süresi, konfluensinde bulunan farklılıkları incelemek için 3 aylık yaştaki, 4 erkek Sprague Dawley 1rkı sıçan (ortalama canlı ağırlıkları yaklaşık $250 \mathrm{~g}$ ) kullandık. İn vitro ekspansiyonda, SVF hücreleri ile karşılaştırıldıklarında ADMKH'ler; yüksek oranda hücresel tutunma, hızlıca fibrolastoid hücre yapısını oluşturma, homojen hücre populasyonu, daha hızlı proliferasyon gösterdi. Sonuç olarak, ADMKH'lerin her 3 pasajda daha fazla oranda plastik yüzeye tutunduğu, daha yüksek proliferasyon kapasitesine sahip olduğu ve in vitro kültürde SVF hücrelerinden daha kısa sürede konfluense ulaştığını gözlemledik. Bu bulgular, çeşitli dokulardan kök hücrelerin izolasyonu ve seçimi ile ilgili ileriki çalışmalara katkıda bulunmasının yanı sıra, ADMKH'ler ve SVF hücreleriyle yapılan klinik deneylerin tasarlanmasına da katkı sağlayacaktır.

Anahtar sözcükler: Adipoz doku kökenli hücreler, mezenkimal kök hücreler, stromal vasküler fraksiyon hücreleri.

\section{Introduction}

Human and animal stem cells have an unrestricted potential for differentiation, self-replication, and self renewal $(6,12,20)$. Mesenchymal stem cells (MSCs) are representative of adult MSCs that have capable of selfrenewing, self-organizing, and have a multi-lineage differentiation potential (23). Stem cells were isolated from adipose tissue by Rodbell and Zuk et al. (18, 29), which were identified as Adipose-Derived Mesenchymal Stem Cells (ADSCs / AD-MSCs / ASCs). In addition to adipose tissue, MSCs have also been isolated from tendons, the periodontal ligament, synovial membrane, trabecular bone, bone marrow, embryonic tissues and skin $(2,10)$. ADSCs' positive cluster differentiation (CD) 
markers are CD90, CD44, CD29, CD105, CD13, CD34, CD73, CD166, CD10, CD49d and CD59 while the most commonly detected negative markers are CD31, CD45, CD14, CD11b, CD19, CD56 and CD146 in ADSCs (12, 17). Stromal Vascular Fraction (SVF) was initially obtained by proteolytic enzymes and centrifugation technique by Rodbell and colleagues (26). MSCs were identified as processed lipoaspirate cells (PLA cells) or SVF (29). SVF has a heterogeneous cell fraction containing stem cells. Different markers CD markers have been reported for ADSCs and SVF cells $(5,11)$. While SVFs express endothelial (progenitor) stem cell surface markers, including CD31, CD34, CD45, and CD105, ADSCs do not express these markers (15). SVF includes a variety of immunotherapeutic cells and MSCs, which can be used freshly after isolation and immediately transplanted into the degenerative tissues (24). However, SVF cells are cultivated under in-vitro standardization for the transplantation or cryopreservation protocol $(1,25)$.

The purpose of this study was to compare ADSCs and SVF cells in terms of the usage of non enzymatic cell isolation, detection of cell adhesion, fibroblastoid cell formation, properties of cell population, cell culture duration of 1st, 2nd and 3rd passage confluency under invitro culture conditions.

\section{Material and Methods}

3 months old, four male Sprague Dawley rats were used (mean of live weight about $250 \mathrm{~g}$ ). Rats were anesthetized by injection of $10 \mathrm{mg} / \mathrm{kg}$ Xylazine and 75 $\mathrm{mg} / \mathrm{kg}$ Ketamine; adipose tissue samples obtained by subcutaneous and abdominal region. All research activities involving animals were approved by The Uludağ University Local Ethical Committee of Animal Experiments (2019-05/01).

Isolation of MSCs derived from adipose tissue: Adipose tissue (3g) was collected from 2 rats and performed to isolate ADSCs by nonenzymatic isolation technique (10). Adipose tissue was transferred into Dulbecco's Phosphate-Buffered Saline (DPBS) solution (Millipore Cat No: BSS-1006) and rinsed. Then, resected tissue material was first minced into $3-4 \mathrm{~mm}^{3}$ small fragments using 2 surgical scalpels. The tissue fragments were seeded onto $\mathrm{T} 25 \mathrm{~cm}^{2}$ tissue culture flasks, and incubated with Rat-MSCs medium (Cat No: RAXMD03011-440). Cell culture medium was supplemented with $10 \%$ FBS, $100 \mathrm{U} / \mathrm{ml}$ penicillin, $100 \mathrm{~g} / \mathrm{ml}$ streptomycin, (Gibco Cat No: TMS-AB2-C), 2 mM L-glutamine (Gibco Cat No: G7513) and heat-inactivated Fetal Bovine Serum (FBS) $20 \%$ (Gibco Cat No: TMS-013-B). T25 flasks were cultivated under $5 \% \mathrm{CO}_{2}$ incubator at $37^{\circ} \mathrm{C}$ in a $96 \%$ humidified atmosphere. ADSCs medium was replaced with fresh medium 3 times a week. Cells at 1st, 2nd and 3rd passages of ADSCs culture were detached with sterile cell scrapers after each of the $70 \%$ cell confluency.

Isolation of SVF derived cells: $3 \mathrm{~g}$ adipose tissue was collected from two rats and performed to isolate SVF cell population by nonenzymatic isolation technique (21). Adipose tissue was transferred into DPBS solution (Millipore Cat No: BSS-1006) and rinsed. For the nonenzymatic SVF isolation; adipose tissue was minced into $3-4 \mathrm{~mm}^{3}$ fragments. Then, $3 \mathrm{~g}$ of adipose tissue and $3 \mathrm{ml}$ $0.09 \%$ serum isotonic were mixed within a sterile $15 \mathrm{ml}$ centrifuge tube. After this step, SVF content were vortexed in $2400 \mathrm{rpm}$ for 2 minutes and centrifuged in $3500 \mathrm{rpm}$ for 4 minutes. Then, the supernatant from the top layer of the tube was discarded, and the pellet contents were filtered through a $70 \mu \mathrm{m}$ cell strainer. This freshly isolated SVF pellet form was cultivated in-vitro T25 flasks under $5 \% \mathrm{CO}_{2}$ incubator at $37^{\circ} \mathrm{C}$ in a $96 \%$ humidified atmosphere. Rat-MSCs medium (Cat no: RAXMD03011-440) containing with $10 \%$ FBS, $100 \mathrm{U} / \mathrm{ml}$ penicillin, $100 \mathrm{~g} / \mathrm{ml}$ streptomycin, (Gibco Cat No: TMSAB2-C), two mM L-glutamine (Gibco Cat No: G7513) and heat-inactivated $20 \%$ Fetal Bovine Serum (FBS) (Gibco Cat No: TMS-013-B). $5 \mathrm{ml}$ cell culture medium was added into each of the flasks and replaced with fresh medium 3 times a week and passaged with cell scraper until 3rd passages.

\section{Results}

ADSCs were observed to adhere to culture flasks within 24 hours and majority of cells were seen to adhere to culture flasks after 48 hours. ADSCs population contained both fibroblast-like cells with spindle shape and migrating cells with round shape, which were prominent on day 3 (Figure 1A). ADSCs reached $70 \%$ confluency on day 8 , and also, the cell population had a homogeneous morphology (Table 1). In ADSCs, there were no adipose tissue residues and no dead tissue fragments were observed on the first passage (Figure 2). The second passage of ADSCs reached $70 \%$ confluency faster compared with the first passage of ADSCs. Homogeneous population of cells with fibroblast-like shape observed on the first passage of ADSCs were still apparent on the second (on day 13) and third passages (on day 18) (Figure $3)$.

In SVF cells, adhesion phase of cells, spindle-like cells, cell migration step, or homogeneous cell population were not detect until day 3. Adherent cells and low cell density at the migrating phase were observed in SVF cells on day 7. Fibroblast-like cells and spindle shape cells were not detected on day 7 but a heterogeneous cell population were observed such as the oval, polygonal and various 
small cells (Figure 1B). Heterogeneous cell population, dead adipose tissue residues and adherent cells were observed in SVF cell culture on day 7. Moreover, SVF cells had a long migration phase, and migrating cells significantly increased on day 14 (Figure 4). The small, residual cells, oval, polygonal shaped cells and low density of fibroblast-like cells were observed from 18 to 21 days in SVF cells. The first passage of SVF cells reached $60 \%$ confluency on day 21 (Figure 5). SVF cells were subcultured for the second and third passages at 60 $\%$ confluency on days 28 and 35 , respectively (Table 1 ).

Table 1. The differences of in-vitro cultures of ADSCs and SVF cells.

\begin{tabular}{lll} 
& ADSCs & SVF cells \\
\hline Cell adhesion & 24 hours & On day 7 \\
Cell migration & 48 hours & On day 14 \\
Fibroblast-like cells & On day 3 & On day 18 \\
Properties of cell population & Homogeneous population & Heterogeneous population \\
1st passage and confluence & On day 8 and $70 \%$ confluence. & On day 21 and $60 \%$ confluence \\
2nd passage confluence & On day 13 and $70 \%$ confluence & On day 28 and $60 \%$ confluence \\
3rd passage confluence & On day 18 and $70 \%$ confluence & On day 35 and $60 \%$ confluence \\
Differences of cell population & Fibroblastoid cells & Fibroblastoid cells, residuel cells, small, oval \\
\end{tabular}

ADSCs: mesenchymal stem cells, SVF cells: stromal vascular fraction cells.

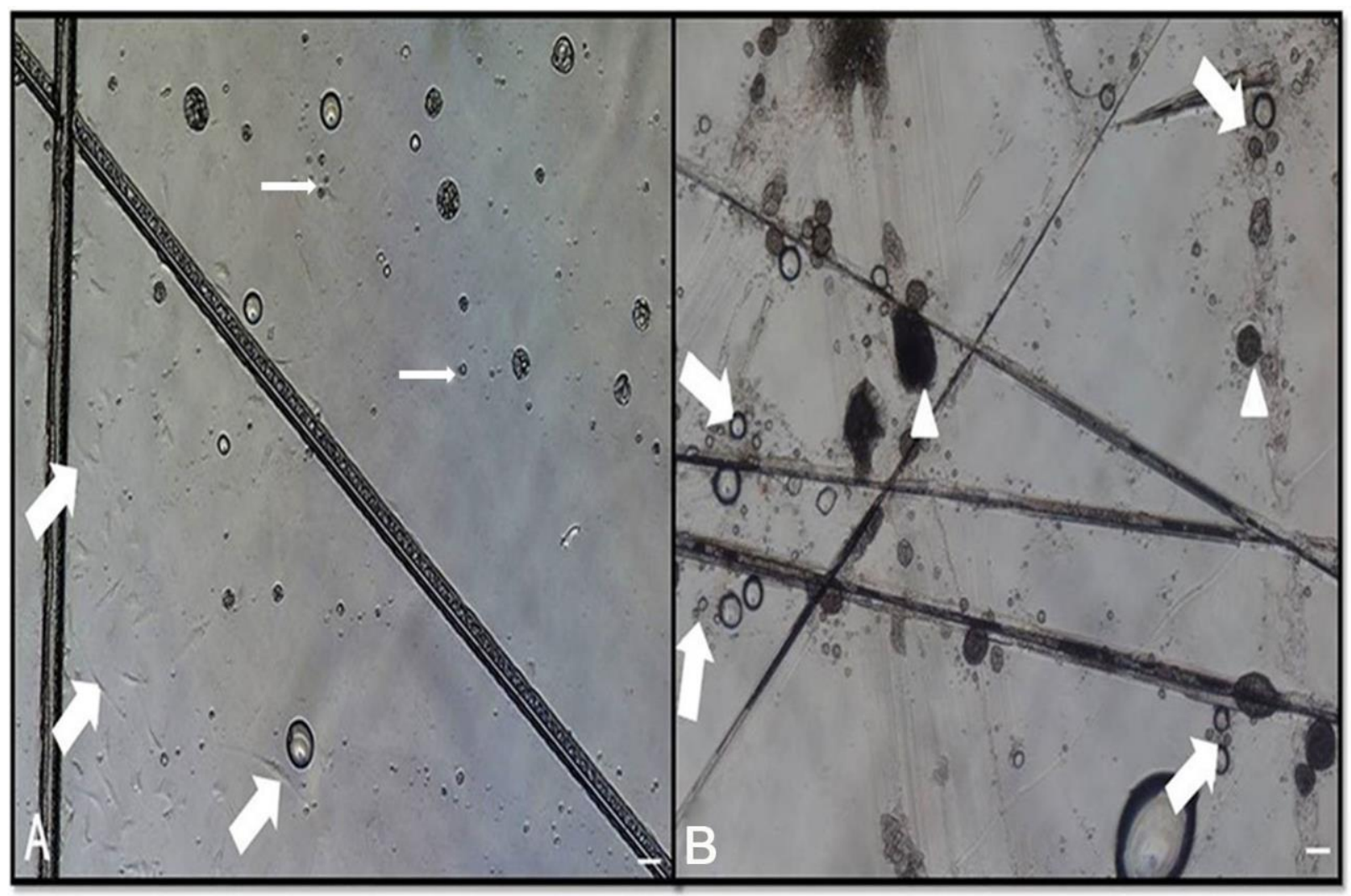

Figure 1. A) Fibroblast-like cells (thick arrows) and round shape of migratory cells in ADSCs (thin arrows); on day 3; B) Low density of cell migrating phase on day 7; heterogeneous cells, oval, polygonal shape and variety form of small cells (thick arrows); dead adipose

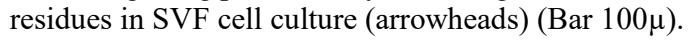




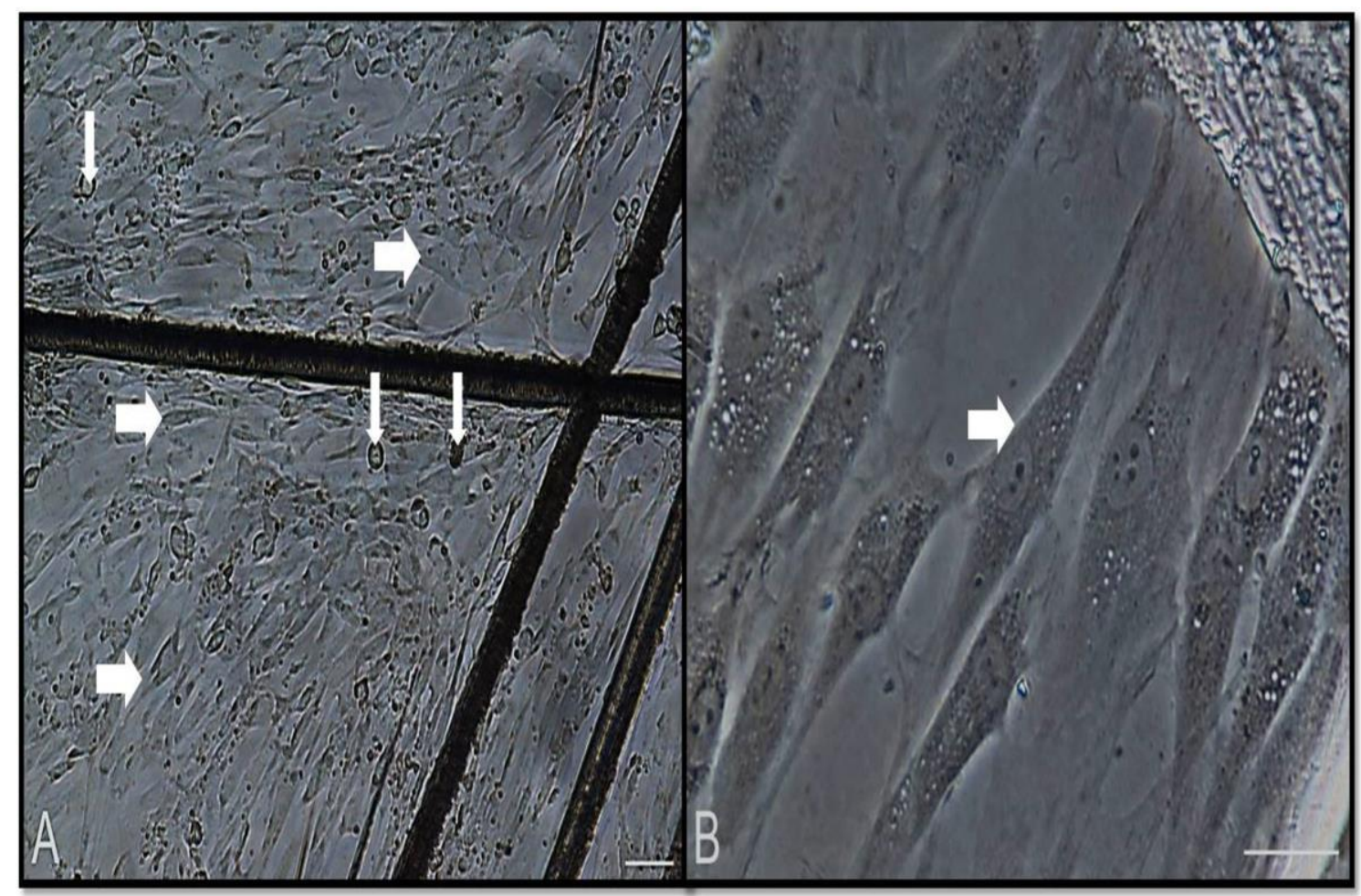

Figure 2. A) First passage $70 \%$ confluency on day 8; migratory cells from adipose tissue (thin arrows); homogeneous and spindle

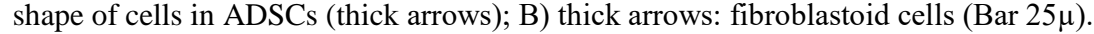

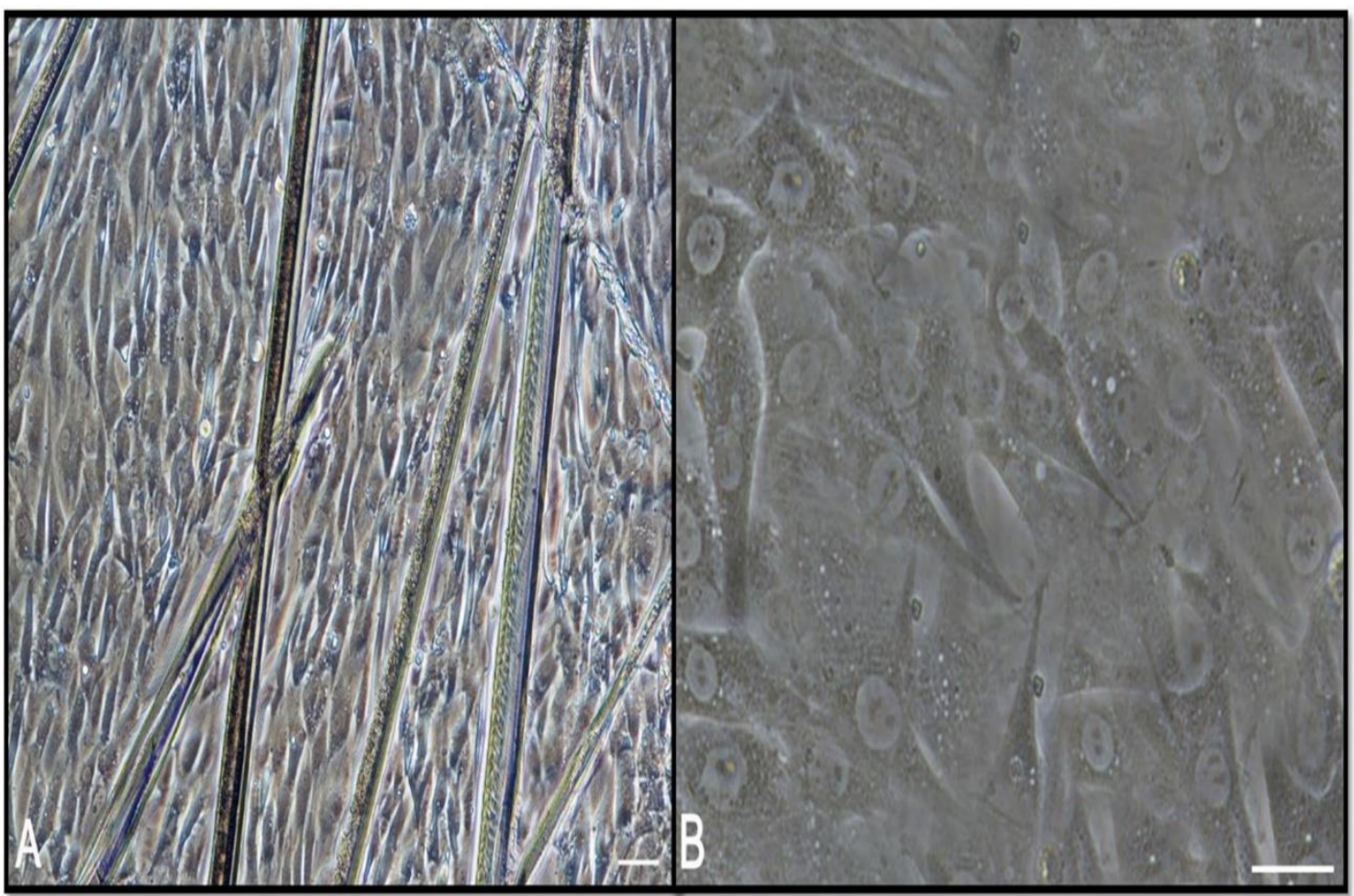

Figure 3. Homogeneous fibroblastoid cells were subcultured for second and third passages in ADSCs on day 13 (A) and 18 (B), respectively $($ Bar $25 \mu)$. 


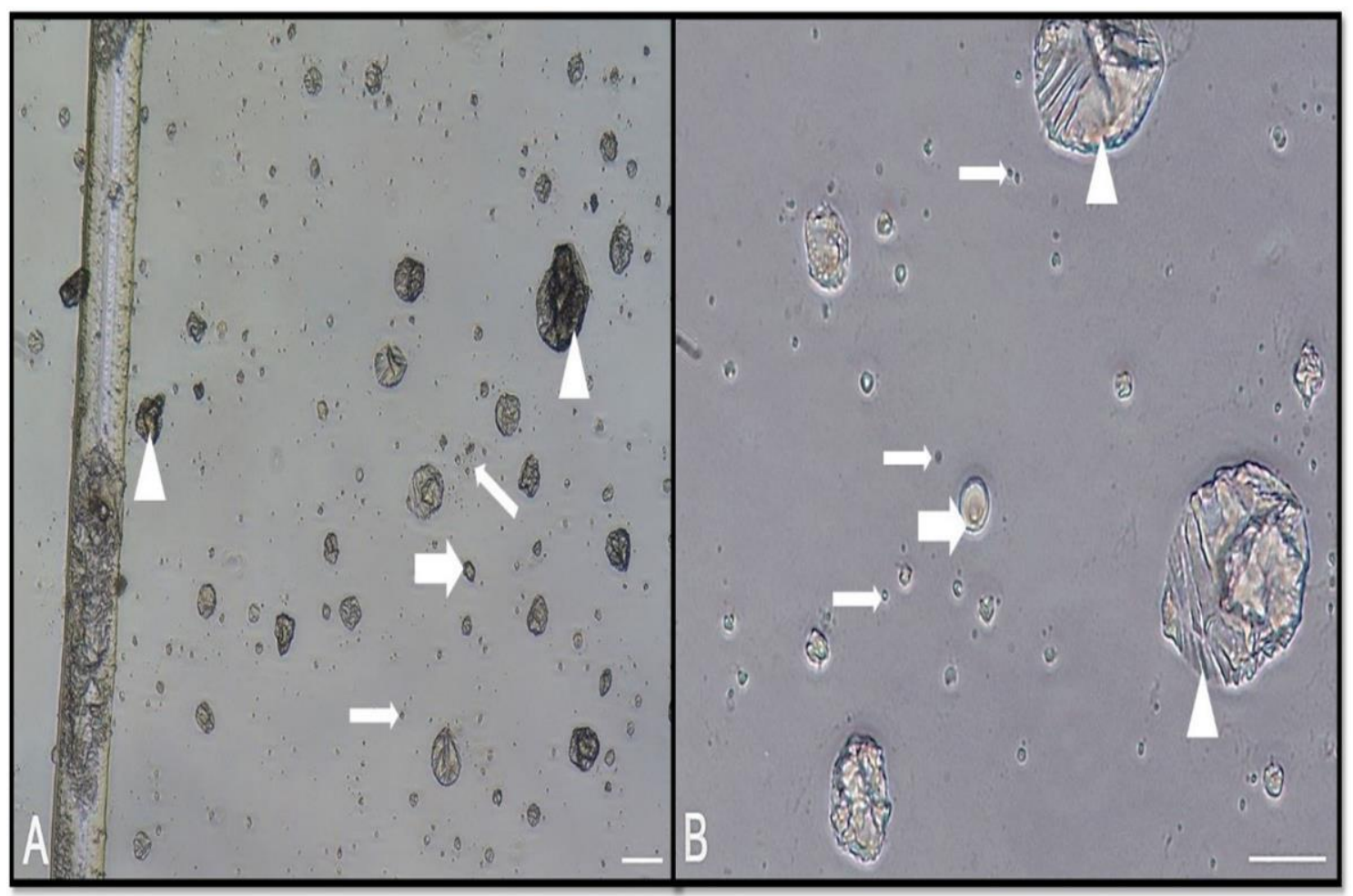

Figure 4. (A and B) Heterogeneous cells (thin arrows), migratory cells (thick arrows) on day 14 and dead adipose tissue residues

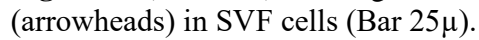

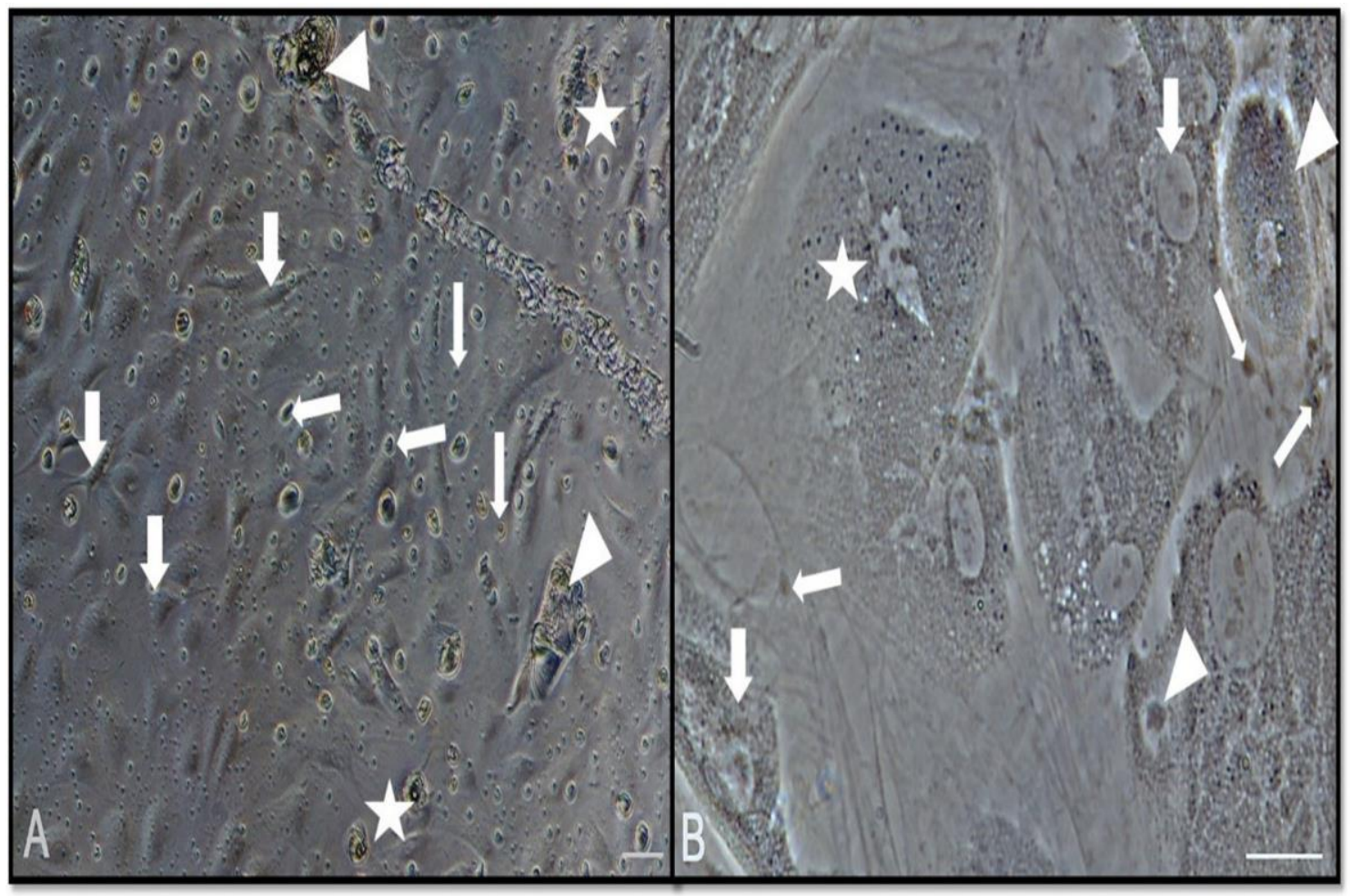

Figure 5. (A and B) SVF cells, approximately $60 \%$ confluency on day 21 and still heterogenous cell population; residual cells of adipose tissue (arrowheads); lower density of fibroblast-like cells (thick arrows); variety form of small, oval and polygonal shaped of heterogeneous cell population (thin arrows); differentiated into heterogeneous cells (asterisks); second and third passages on day 28

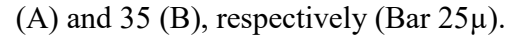




\section{Discussion and Conclusion}

Aronowitz et al. (3) reported that both enzymatic and non-enzymatic isolation methods for SVF cells were equally effective and safe. Zhu et al. (28) reported that non- enzymatic isolation process is less costly than enzymatic isolation process. Additionally, Varma et al. (26) reported that enzymatically isolated SVF cells reached first passage only in a week. However, López et al. (14) reported that enzymatic isolation process adversely affected cell viability and differentiation capacity of SVF cells. In our study SVF cells reached the first passage within three weeks. Katsara et al. (13) demonstrated that (5-12-week-old mice) adolescent mice have higher proliferation capacity than adults (13-34week-old mice) and they noted more cells obtained from male mice at $1 \mathrm{st}, 2 \mathrm{nd}$, and 3rd passages compared to female mice. In the present study, 12-week-old adolescent male Sprague Dawley rats were chosen for the cell isolation and ADSCs had higher proliferative capacity as compared to SVF cells. We speculate that the differences in rats' sex properties and ages may have affected ADSCs and SVF cells during the cell culture process. High proliferative capacity of ADSCs after 24 hours of culture were also reported by other studies $(9,16,19,21,30)$. In accordance with our study, Nadri et al. (16) reported that spindle-shaped ADSCs at the 1st passage reached complete confluency after one week of culture. In the present study, the higher density of adherent cells and earlier 1st confluency were observed in ADSCs compared with SVF cells. Thus, our study suggests that ADSCs have a better cell proliferation capacity compared with SVF cells. Zhu et al. (29) reported that ADSCs have extensive confluency propensity compared with bone marrowderived stem cells (BMSCs) (29). Condé Green et al. (8) noted that BMSCs and SVF cells consisted of the heterogeneous cell population (such as endothelial cells, leukocytes, vascular smooth muscle cells, ADSCs and pericytes adhered), which may have affected in-vitro culture duration phase. Furthermore, the present study showed that compared with SVF cells, ADSCs exhibited a higher density of adherent cells, an earlier migratory phase and faster growth. We speculate that a more homogenous cell population and better survival capacity may have contributed to enhanced proliferative capacity of ADSCs, as compared with SVF cells. Asumda et al. (4), Sun et al. (23) and Zhu et al. (29) studies suggest that the cross-interaction between endothelial cells and stem cells may have been responsible for diminished proliferative capacity of SVF cells. Chazenbalk et al. (7) study reported that SVF cells expressed a lower density of progenitor stem cells than ADSCs. And also, Sancak (19) and Peng et al. (17) study reported that in ADSCs have more cell adhesion and cell-forming ability. Furthermore, Shah et al. (22), Van et al. (26), Varma et al. (27) and You et al. (28) reported that SVF cells present a hematopoietic cell population on advanced passages and have a heterogeneous cellular composition, secrete different cytokine and growth factors. Also, in our study, the population of SVF cells showed a heterogeneous cell population such as spindle, polygonal or oval shaped cells. As a result of heterogeneity in cell population, SVF cells required longer cultivation phase as compared with ADSCs.

In conclusion; in present study, we showed that ADSCs have a better adhesive ability, higher proliferative capacity in all passages and require shorter time to reach confluency compared with SVF cells in vitro. These findings may contribute to future studies that deal with isolation and selection of stem cells from various tissues, as well as design clinical trials based on ADSCs and SVF.

\section{Financial Support}

This research received no grant from any funding agency/sector

\section{Ethical Statement}

This study was approved by the Uludağ University Local Ethical Committee of Animal Experiments (201905/01).

\section{Conflict of Interest}

The authors declared that there is no conflict of interest.

\section{References}

1. Agostini F, Rossi FM, Aldinucci D, et al (2018): Improved GMP compliant approach to manipulate lipoaspirates, to cryopreserve stromal vascular fraction, and to expand adipose stem cells in xeno-free media. Stem Cell Res Ther, 9, 130.

2. Aguena M, Dalto Fanganiello R, Tissiani LAL, et al (2012): Optimization of parameters for a more efficient use of adipose-derived stem cells in regenerative medicine therapies. Stem Cells Int, 303610.

3. Aronowitz JA, Lockhart RA, Hakakian CS (2015): Mechanical versus enzymatic isolation of stromal vascular fraction cells from adipose tissue. Springerplus, 23, 713.

4. Asumda FZ, Chase PB (2011): Age-related changes in rat bone-marrow mesenchymal stem cell plasticity. BMC Cell Biol, 12, 44.

5. Boquest AC, Shahdadfar A, Fronsdal K et al (2005): Isolation and transcription profiling of purified uncultured human stromal stem cells: alteration of gene expression after in vitro cell culture. Mol Biol Cell, 16, 1131-1141.

6. Bongso A, Fong C (2009): Human Embryonic Stem Cells: Their Nature, Properties, and Uses. 1-18 In: H Baharvand (Ed). Trends in Stem Cell Biology and Technology. Humana Press, New York.

7. Chazenbalk G1, Bertolotto C, Heneidi S, et al (2011): Novel Pathway of Adipogenesis through Cross-Talk between Adipose Tissue Macrophages, Adipose Stem Cells and Adipocytes: Evidence of Cell Plasticity. PLoS One, 6 , e17834. 
8. Condé Green A, Kotamarti VS, Sherman LS, et al (2016): Shift toward Mechanical Isolation of Adiposederived Stromal Vascular Fraction: Review of Upcoming Techniques. Plastic and reconstructive surgery. Plast Reconstr Surg Glob Open, 4, e1017.

9. Csaki C, Matis U, Mobasheri A, et al (2007): Chondrogenesis, osteogenesis and adipogenesis of canine mesenchymal stem cells: a biochemical, morphological and ultrastructural study. Histochem Cell Biol, 128, 507-520.

10. Ghorbani A, Jalali SA, Varedi M (2014): Isolation of adipose tissue mesenchymal stem cells without tissue destruction: a non-enzymatic method. Tissue Cell, 46, 5458.

11. Gimble JM, Guilak F (2003): Differentiation potential of adipose derived adult stem (ADAS) cells. Curr Top Dev Biol, 58, 137-160.

12. Gimble JM (2003): Adipose tissue-derived therapeutics. Expert Opin Biol Ther, 3, 705-713.

13. Katsara O, Mahaira LG, Iliopoulou EG, et al (2011): Effects of donor age, gender, and in vitro cellular aging on the phenotypic, functional, and molecular characteristics of mouse bone marrow-derived mesenchymal stem cells. Stem Cells Dev, 20, 1549-1561.

14. López C, Ajenjo N, Muñoz-Alonso MJ, et al (2008): Determination of viability of human cartilage allografts by a rapid and quantitative method not requiring cartilage digestion. Cell Transplant, 17, 859-864.

15. Mildmay-White A, Khan W. (2009): Cell surface Markers on Adipose-Derived Stem Cells: A Systematic Review. Curr Stem Cell Res Ther, 12, 484-492.

16. Nadri S, Soleimani M (2007): Isolation murine mesenchymal stem cells by positive selection. In Vitro Cell Dev Biol Anim, 43, 276-282.

17. Peng L, Jia Z, Yin X, et al (2008): Comparative analysis of mesenchymal stem cells from bone marrow, cartilage, and adipose tissue. Stem Cells Dev, 17, 761-773.

18. Rodbell, M (1964): The metabolism of isolated fat cells. Compr Physiol, 47, 471-482.

19. Sancak IG, Özen A, Bayraktaroğlu AG, Ceylan A, Can P. (2016): Characterization of mesenchymal stem cells isolated from the adipose tissue of young and old dogs. Ankara Univ Vet Fak Derg, 63, 297-302.
20. Satija NK, Singh VK, Verma YK, et al (2009): Mesenchymal stem cell-based therapy: a new paradigm in regenerative medicine. J Cell Mol Med, 13, 4385-4402.

21. Sarraf CE, Otto WR, Eastwood M (2011): In vitro mesenchymal stem cell differentiation after mechanical stimulation. Cell Prolif, 44, 99-108.

22. Shah FS, Wu X, Dietrich M, et al (2013): A non-enzymatic method for isolating human adipose tissue-derived stromal stem cells. Cytotherapy, 15, 979-985.

23. Sun CK, Yen CH, Lin YC, et al (2011): Autologous transplantation of adipose-derived mesenchymal stem cells markedly reduced acute ischemia-reperfusion lung injury in a rodent model. $\mathrm{J}$ Transl Med, $\mathbf{9}, 118$.

24. Strioga M, Viswanathan S, Darinskas A, et al (2012): Same or not the same? Comparison of adipose tissuederived versus bone marrow-derived mesenchymal stem and stromal cells. Stem Cells Dev, 21, 2724-2752.

25. Thirumala S, Gimble JM, Devireddy RV (2010): Cryopreservation of stromal vascular fraction of adipose tissue in a serum-free freezing medium. J Tissue Eng Regen Med, 4, 224-232.

26. Van Dijk A, Naaijkens BA, Jurgens WJFM, et al (2011): Reduction of infarct size by intravenous injection of uncultured adipose derived stromal cells in a rat model is dependent on the time point of application. Stem Cell Res, 7, 219-229.

27. Varma MJ, Breuls RG, Schouten TE, et al (2007): Phenotypical and functional characterization of freshly isolated adipose tissue-derived stem cells. Stem Cells Dev. 16, 91-104.

28. You D, Jang MJ, Kim BH, et al (2015): Comparative study of autologous stromal vascular fraction and adiposederived stem cells for erectile function recovery in a rat model of cavernous nerve injury. Stem Cells Transl Med, $\mathbf{4}$, 351-358.

29. Zhu Y, Liu T, Song K, et al (2008): Adipose-derived stem cell: a better stem cell than BMSC. Cell Biochem Funct, 26, 664-675.

30. Zuk PA, Zhu M, Mizuno H, et al (2001): Multilineage cells from human adipose tissue: implications for cell-based therapies. Tissue Eng, 7, 211-28. 